\title{
Search for Molecular Markers of Wheat Resistance to Fungal Pathogens
}

\author{
Liubov G. Yarullina1,2, Svetlana V. Veselova1, Rinat I. Ibragimov², Irina A. Shpirnaya2, \\ Rita I. Kasimova1, Albina R. Akhatova1, Vyacheslav 0. Tsvetkov', Igor V. Maksimov'1 \\ ${ }^{1}$ Institute of Biochemistry and Genetics of Ufa Scientific Centre of Russian Academy of Sciences, Ufa, Russia \\ ${ }^{2}$ Bashkir State University, Ufa, Russia \\ Email: yarullina@.bk.ru
}

Received 15 May 2014; revised 25 June 2014; accepted 18 July 2014

Copyright @ 2014 by authors and Scientific Research Publishing Inc.

This work is licensed under the Creative Commons Attribution International License (CC BY).

http://creativecommons.org/licenses/by/4.0/

c) (i) Open Access

\begin{abstract}
Functional traits, potentially associated with resistance to infection, were investigated in cultivars of bread wheat. Plant responses to infection by hemibiotrophic fungus Stagonospora (Septoria) nodorum were studied under laboratory conditions. Infection-induced up-regulation of genes coding for class III peroxidase, oxalate oxidase and protease inhibitor was greater in leaves with reduced disease symptoms (percentage of chlorotic or necrotic leaf area). Similar association was detected between activity of pectinase inhibitors and disease severity. Resistant cultivar also differed from the susceptible one by increased content of $\mathrm{H}_{2} \mathrm{O}_{2}$ in infected tissues and more intensive deposition of lignin. We discuss possibility of using these functional traits in plant breeding for increased stress tolerance.
\end{abstract}

\section{Keywords}

Infection, Peroxidase, Oxalate Oxidase, Protease Inhibitor, Pectinase Inhibitor, PR-Gene Expression, $\mathrm{H}_{2} \mathrm{O}_{2}$, Lignin, Wheat

\section{Introduction}

Under natural conditions, plants are exposed to various biotic and abiotic stress factors and their survival depends on ability to protect themselves from detrimental effects of adverse environment. From the view point of importance for the lives of people, pivotal aspect of plant resistance is in maintaining productivity under the detrimental influence of pathogens. Possible approach to the discovery of the mechanisms responsible for resistance to pathogens may be in comparison of functional traits related to biotic stresses in different plant cultivars. We evaluated the transcriptional activity of genes coding for class III peroxidase (PRX), oxalate oxidase (OXO), 
proteinase inhibitor (BSI) as indicators related to plant resistance against infection. It is known that these proteins are referred to as pathogenesis-related (PR proteins) [1]-[3]. Moreover, accumulation of hydrogen peroxide and lignin deposition were followed in cultivars with contrasting resistance to wheat pathogen.

Peroxidases play an important role in protective responses to infection of plant cells [4]. Due to their properties and diversity of molecular forms, peroxidases represent one of the key protective systems, including those involved in utilization of $\mathrm{H}_{2} \mathrm{O}_{2}$ excess and lignification processes [5]. The main function of oxalate oxidase is to participate in the degradation of oxalic acid, which is a pathogenic factor in a large number of crop pathogens, including S. nodorum [6]. Formed $\mathrm{H}_{2} \mathrm{O}_{2}$ as a signaling molecule can induce the development of a protective response in the plant cells, as well as provide effective flow of one of the main defense mechanisms of plantsformation and deposition of lignin [7] [8].

Hydrolytic enzymes of pathogens comprise important factor of their virulence and aggressiveness. To neutralize this, pathogenic factor plants produce different hydrolase inhibitors. Participation of proteinase and pectinase inhibitors in plant defense reactions has been investigated extensively [9]. However, there are always new experimental data that extend the existing concepts in this area.

Thus, the study of physiological parameters such as the transcriptional activity of genes for protective proteins (peroxidase, oxalate oxidase, hydrolase inhibitors) in infected tissues may reveal the molecular criteria for the selection of resistant plant forms.

\section{Materials and Methods}

As an object of research we have chosen five cultivars of wheat (Triticum aestivum L.) which differed in field resistance to the pathogen according to preliminary data. Wheat seeds were obtained from the Bashkir scientific research Institute of Agriculture of Russian Agricultural Academy. Seedlings of bread wheat, cvs. Omskaya 35 (Omsk 35) and 36, Simbirka (Sim), Bashkirskaya 26 (Bash) and Kazakhstanskaya 10 (Kaz) (Cheshminskaya Research Station, Russia) were grown in containers filled with 0.1 strength Hoagland-Arnon [10] nutrient solution in a controlled-environment growth chamber (MLR-350H, Sanyo, Japan) for 7 d, 16-h photoperiod and at $21^{\circ} \mathrm{C}$.

For inoculation of plants and estimation of their susceptibility to infection by fungus pathogen fully unfolded leaves of 7-d-old plants were cut and placed in moist chambers, sections were covered with cotton wool wetted with $40 \mathrm{mg} \cdot \mathrm{ml}^{-1}$ benzimidazole and incubated in darkness at room temperature for $24 \mathrm{~h}$. Then leaf segments were inoculated with suspension of Stagonospora (Septoria) nodorum spores $\left(10^{6} \mathrm{ml}^{-1}\right)$, isolated by authors from local fungal populations. Inoculated leaves were incubated at root temperature for $24 \mathrm{~h}$ and then returned to illuminated conditions described above.

The diseased areas of the leaf (chlorotic and necrotial areas) were assessed $120 \mathrm{~h}$ after inoculation, expression of the genes for oxalate oxidase, peroxidase and protease inhibitor were estimated 24 and $48 \mathrm{~h}$ after inoculation. Uninfected plants were used as controls.

Transcriptional activity of the genes was estimated as described [11]. Total RNA was isolated from plant tissues by TRIzol (Molecular Research Center, Inc, USA) extraction. RNA was dissolved in TE buffer (10 mMTris-HCl and $1 \mathrm{mM}$ EDTA), $\mathrm{pH}$ 8.0, and its concentration was measured using a Smart Spec TM Plus spectrophotometer (Bio-Rad, United States) at A 260/A 280. Before PCR analysis, the concentrations of all RNA samples were equalized. cDNA synthesis was performed with oligonucleotide primers and an M-MVL reverse transcriptase as recommended by manufacturer (Fermentas, Lithuania). Primers to amplify genes were designed by using Primer Select software (DNAStar). For Class III peroxidase gene TaPrx16 (TC151917) specific primers were 5'-ttc-gac-aag-cag-tac-tac-cac-aa-3' (forward primer) and 5'-ccg-aag-tcc-gag-aag-aac-tg-3' (reverse primer) flanking 220 bp conservative region. For oxalate oxidase gene OXO1 (GrainGenes Sequence Report AJ556991) specific primers were 5'-atg-act-tcc-tct-tct-cgt-cca-ag-3' (forward primer) and 5'-gga-gct-gaa-gagtgt-caa-tgg-3' (reverse primer) flanking 410 bp conservative region. For protease inhibitor gene (EU293132.1) Bsi1 [12] 5'-ggg-ccc-tgc-aag-aag-tac-tg-3' (forward primer) and 5'-aca-cgc-ata-ggc-acg-atg-ac-3' (reverse primer). Amplification of constitutively expressed gene of tubulin (GenBank: DQ435668.1) was used as a positive control. For tubulin 5'-cac-aca-gca-gat-gtg-gga-ct-3' (forward primer) and 5'-gtg-gag-ttg-cca-atg-aag-at-3' (reverse primer). The data obtained were processes using a LabWorks 4.6 computer program (UVP, United States) supplied. Computer analysis of amino acid and nucleotide sequences was carried out by means of software Lasergene (DNASTAR, Inc. USA). 
Activity of pectolytic enzymes was evaluated using gel plates prepared as described previously [13] with apple pectin as a substrate. Pectin solution was mixed with agarose solution in acetate buffer, and then calcium acetate solution was added. Finally, concentrations of ingredients in the mixture were as follows: agarose$1.5 \%$, pectin-1\%, calcium acetate- $0.5 \%$. To assay activity of pectinases and their inhibitors wheat leaves were grinded with quartz sand and proteins extracted with distilled water in a ratio of $1: 5$ for $2 \mathrm{~h}$ at $4{ }^{\circ} \mathrm{C}$. The extract was filtered through filter paper and centrifuged at $3500 \mathrm{~g}$ for $10 \mathrm{~min} .20 \mu \mathrm{l}$ of supernatant was added to the wells of the gel plates. To accomplish the hydrolysis of immobilized pectin cuvette with gel plate was covered by lid and incubated for $9 \mathrm{~h}$ at $37^{\circ} \mathrm{C}$. Effects of pectinases were evaluated by treating plates with $10 \%$ copper acetate. The gel regions containing hydrolyzed pectin were developed as the light areas on the blue background. The enzyme activity was calculated by measuring the size of the gel region with the hydrolyzed substrate around each well. The activity of the enzyme catalyzing the hydrolysis of the substrate in the gel region with the size of $1 \mathrm{~mm}^{2}$ was considered as arbitrary milliunit $(\mathrm{mU})$. To assay activity of pectinase inhibitors plant extract was mixed with equal volume of $100 \mu \mathrm{g} \cdot \mathrm{ml}^{-1}$ Aspergillus niger (Sigma, USA) and added into the wells. Activity of inhibitor was calculated as the difference between values for $50 \mu \mathrm{g} \cdot \mathrm{ml}^{-1}$ Aspergillus niger pectinase and the mixture of pectinase and plant extract. The amount of the inhibitor decreasing enzyme activity by $1 \mathrm{mU}$ was considered as 1 milli unit of the inhibitor activity (mIU).

Concentration of hydrogen peroxide was measured according to the method [14], using xylenol orange in the presence of $\mathrm{Fe}^{2+}$. Then the mixture was centrifuged for $10 \mathrm{~min}$ at $8000 \mathrm{~g}$. Optical density of the complex was measured at $560 \mathrm{~nm}$ at spectrophotometer BioSpec-Mini (Shimadzu, Japan).

Autofluorescence of lignin in the leaf sections fixed with $96 \%$ ethanol 2 days after inoculation was followed with the help of confocal laser scanning microscope (CLSM) LSM-510 on the base of inverted microscope Axiovert $200 \mathrm{M}$ (Carl Zeiss, Germany). For autofluorescence excitation $30 \mathrm{~m}$ Wagron laser with wave length $488 \mathrm{~nm}$, dichroic mirror $490 \mathrm{~nm}$ and $505 \mathrm{~nm}$ light pass filter [15] have been used.

$24 \mathrm{~h}$ after inoculation accumulation of $\mathrm{H}_{2} \mathrm{O}_{2}$ in infected leaf tissues was measured with the help of vital staining of leaf sections placed in $0.1 \mathrm{M}$ phosphate buffer, $\mathrm{pH} 6.2$, containing $1 \mathrm{mg} / \mathrm{ml}$ 3.3-diaminobenzidine (DAB), incubated under vacuum during $30 \mathrm{~min}$ and for $6 \mathrm{~h}$ under ambient temperature [16]. After staining leaf sections were fixed in $96 \%$ ethanol and boiled for $10 \mathrm{~min}$. After boiling leaves were placed into $50 \%$ glycerol solution and $\mathrm{H}_{2} \mathrm{O}_{2}$ were registered with the help of digital microscope BZ8100E (Keyence, Japan).

Statistical analysis was performed using Statistica 6.0 (StatSoft). The repetition of the experiments was not less than 3 in the case of the analysis of biochemical parameters and at least 15 in the analysis of expression. The figure shows the average and standard error as a measure of error. Correlation parameters were evaluated using Pearson criterion.

\section{Results}

Observation of disease symptoms on leaves of different wheat cultivars showed different extent of fungus development. Thus weak chlorotic and necrotic areas had already appeared at the sites of spore application $24 \mathrm{~h}$ after inoculation of leaves of Kaz. Symptoms of leaf blotch disease were observed 48 hours after inoculation on leaves of Omsk 36, Sim, Bash and Kaz as weak leaf bleaching with subsequent leaf browning, while $72 \mathrm{~h}$ after inoculation disease symptoms became apparent as brown spots with fluffy mycelium plaque. Within the specified time mild disease symptoms developed on leaves of Omsk 35.

In the Table 1 the genotypes are ranked in descending order according to leaf blotch disease severity calculated as chlorotic or necrotic areas $120 \mathrm{~h}$ after inoculation. The table shows that leaves of Kaz developed the most severe disease symptoms, while those of Omsk 35 exhibited them to the least extent. Thus according to the size of infected area, plants of Omsk 35 were the most and those of Kaz the least resistant to infection. Cultivars Omsk 36, Sim and Bash occupied an intermediate position according to these characteristics.

Inoculation increased PRX gene expression in leaves of Omsk 35 and 36 and Sim (Figure 1(a)). This was most pronounced in case of Omsk 35. Comparison of data obtained 24 and $48 \mathrm{~h}$ after inoculation showed that the gene expression increased with time in leaves of Omsk 35 and 36 and decreased in those of Sim. Expression of PRX gene in leaves of Bash and Kaz did not change significantly in comparison with control (mock-inoculated plants). Up-regulation of gene expression induced by inoculation was significantly negatively correlated to disease severity and correlation coefficient raised with time $(r=-0.9$ and -0.94 at $p \leq 0.05$ and $p \leq 0.01$, according to Pearson criterion, 24 and $48 \mathrm{~h}$ after inoculation correspondingly). 
Table 1. Disease severity (chlorotic and necrotic leaf areas, $\mathrm{mm}^{2}, \mathrm{n}=10$ ) of different bread wheat cultivars.

\begin{tabular}{cc}
\hline Ultivars & Subhead \\
\hline Omskaya 35 & $7.3 \pm 0.3$ \\
Omskaya 36 & $9.1 \pm 0.4$ \\
Simbirka & $12.6 \pm 0.9$ \\
Bashkirskaya 26 & $15.9 \pm 1.1$ \\
Kazakhstanskaya 10 & $19.6 \pm 1.3$ \\
\hline
\end{tabular}

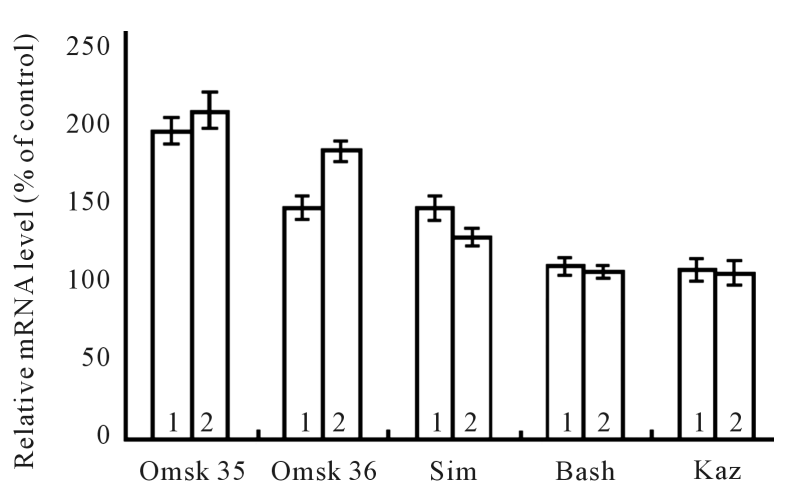

(a)

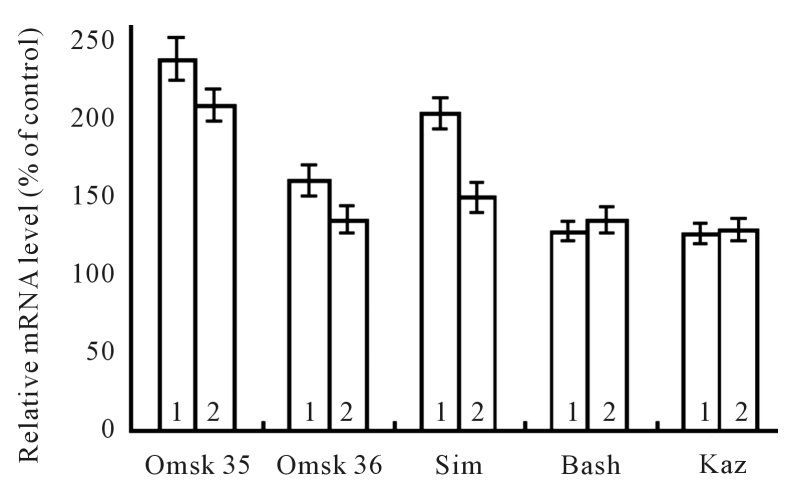

(b)

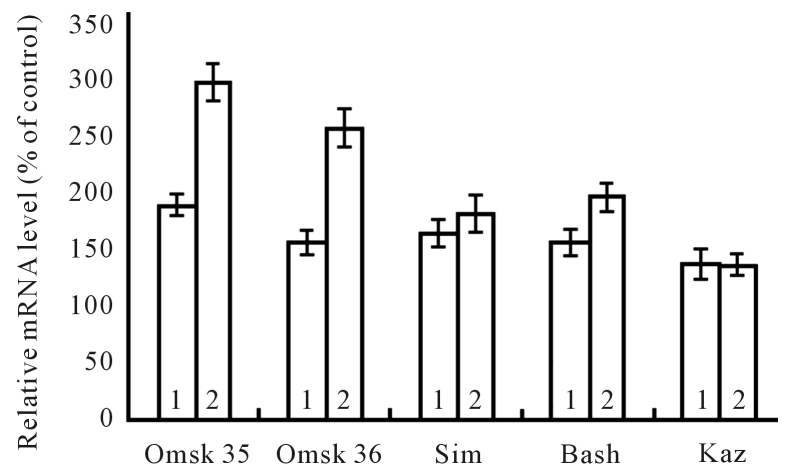

(c)

Figure 1. Effect of infection of isolated bread wheat leaves by S. nodurum on relative PRX (a), OXO (b) and BSI (c) mRNA levels assayed 24 (1) and 48 (2) h after inoculation.

Inoculation increased expression of OXO gene in all studied cultivars (Figure 1(b)). Although the transcript level of this gene mostly declined with time, it remained higher than in control. Maximal transcript level was in leaves of Omsk 35 and minimal in Bash and Kaz. Ranking the rest two cultivars for this trait changed as compared to that for expression of PRX gene (Omsk 36 and Sim were swapped in their ranking). As a result correlation between transcript level of OXO gene and disease severity was statistically insignificant ( $\mathrm{r}$ about $-0.7, \mathrm{p}>$ 0.05 according to Pearson criterion).

Transcript level of BSI gene increased significantly in inoculated leaves of all cultivars tested (maximal expression level was again in leaves of Omsk 35) and was significantly higher $48 \mathrm{~h}$ than 24 after inoculation in leaves of all cultivars except Kaz 10 and Sim (Figure 1(c)). $48 \mathrm{~h}$ after inoculation the gene expression was significantly negatively correlated to disease severity $(r=-0.94)(24 \mathrm{~h}$ after inoculation correlation was statistically insignificant).

In control un-inoculated leaves the difference in pectolytic activity between cultivars was not great (Figure 2(a)). Maximal activity in leaves of Omsk 35 was only 1.2 greater than minimal value detected in leaves of Sim. 
Inoculation increased the difference between cultivars and relation between maximum observed in Bash leaves and minimum in Omsk 35 was already 1.6. This increase in the variability of the trait resulted from the inoculation-induced increase in pectolytic activity in some cultivars (Sim, Bash, Kaz) and its decline in the others (Omsk 35 and 36). Activity of pectinase inhibitor was lowest in un-inoculated leaves of Kaz and although it increased with inoculation up to the level of Bash, it remained lower than in all other cultivars (Figure 2(b)). Inoculation increased activity of pectinase inhibitor in leaves of Omsk 35 and decreased it in Sim. These inoculation induced changes in activity of inhibitor resulted in appearance of strong negative correlation between this functional trait and disease severity $(\mathrm{r}=-0.95, \mathrm{p}<0.01$ according to Pearson criterion).

Infection induced accumulation of $\mathrm{H}_{2} \mathrm{O}_{2}$ in plants contrasting in their resistance, $\mathrm{H}_{2} \mathrm{O}_{2}$ content increasing to greater degree in leaves of susceptible cultivar Kaz 10 than in resistant cultivar Omsk 35 (Figure 3). It is important to emphasize that in infected leaves of Omsk 35 high concentration of $\mathrm{H}_{2} \mathrm{O}_{2}$ maintained throughout the whole experiment, while in susceptible cultivar Kaz 10 its transitory increase $24 \mathrm{~h}$ after infection was followed by decline.

Generation of $\mathrm{H}_{2} \mathrm{O}_{2}$ in the tissues of wheat leaves was also studied with the help of DAB staining (Figure 4). Histochemical analysis revealed significant generation of $\mathrm{H}_{2} \mathrm{O}_{2}$ in the zone of pathogen penetration into the leaves of resistant cultivar Omsk 35 detected $24 \mathrm{~h}$ after infection unlike susceptible cultivar Kaz 10 (Figure 4(a), Figure 4(c)). At the same time, enhancement of $\mathrm{H}_{2} \mathrm{O}_{2}$ production in leaves of Omsk 35 was accompanied by intensive lignin deposition in cells walls of leaf tissues in the zone of infection (Figure 4(d)). In the leaves of susceptible cultivar Kaz 10 there was insignificant lignin autofluorescence in the zone of pathogen localization (Figure 4(b)).

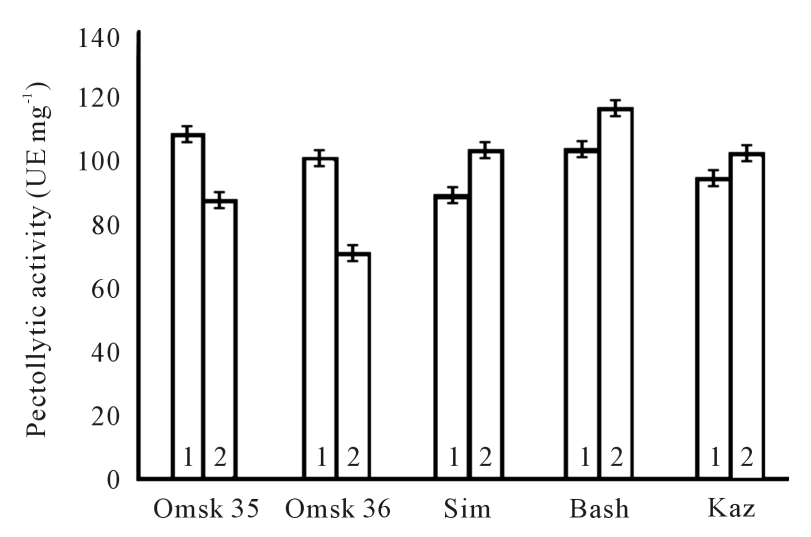

(a)

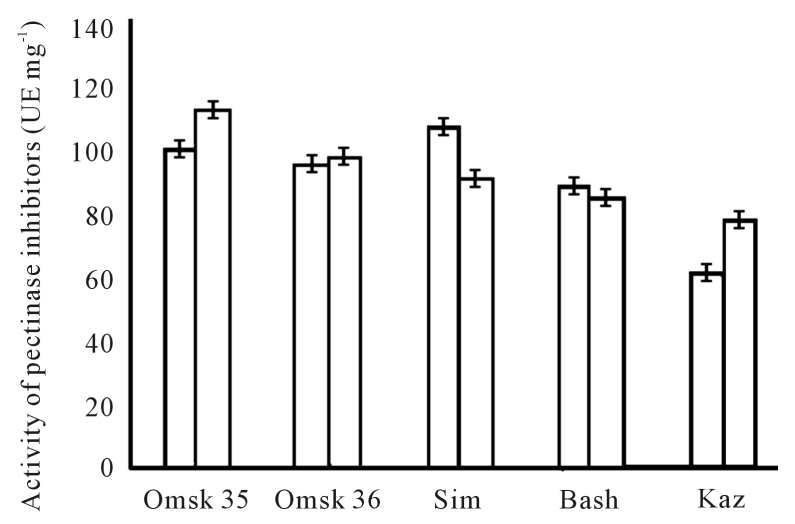

(b)

Figure 2. Pectolytic activity (a) and activity of pectinase inhibitors (b) in isolated bread wheat leaves $48 \mathrm{~h}$ after infection by S. nodurum: 1 -infec; 2-un-inoculated (contr).

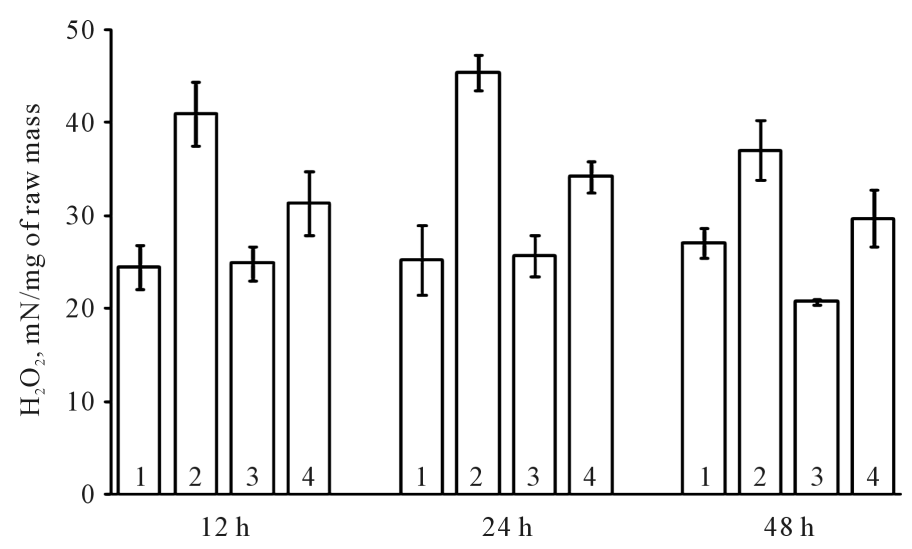

Figure 3. The containing of $\mathrm{H}_{2} \mathrm{O}_{2}$ in wheat leaves of resistant cv. Omsk $35(1,2)$ and susceptible cv. $\operatorname{Kaz}(3,4): 1,3$ - contr, 2, 4-infec. 

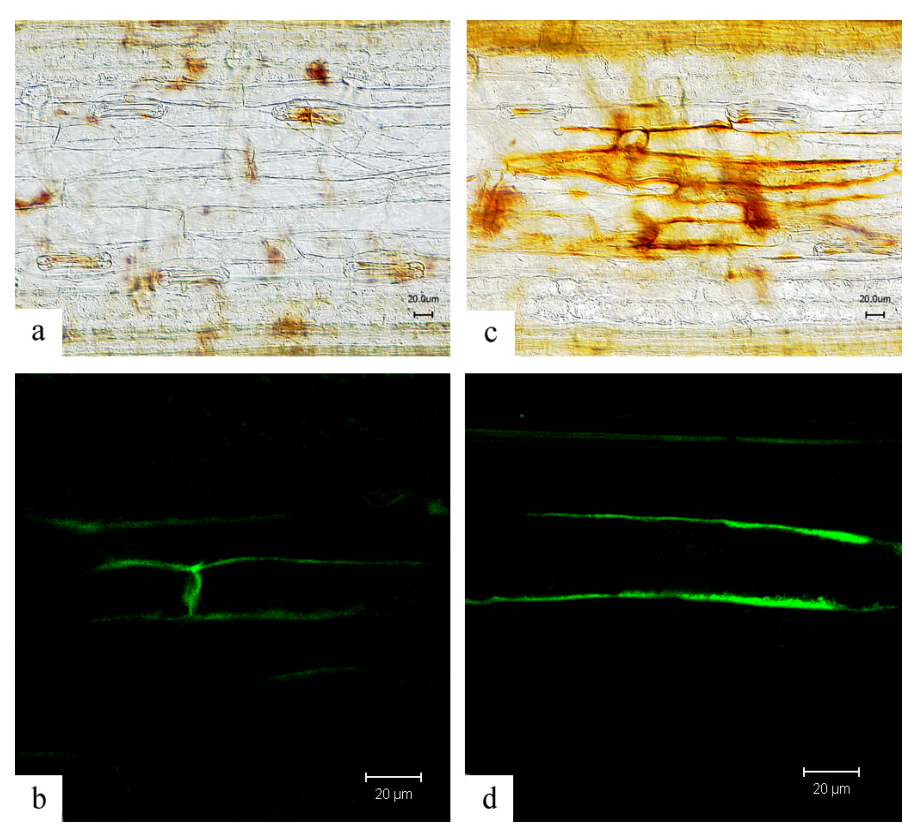

Figure 4. Accumulation of $\mathrm{H}_{2} \mathrm{O}_{2}$ (a), (c) and lignin (b), (d) in leaves of wheat cultivar Kaz (a), (b) and Omsk 35 (c), (d) infected by S. nodorum.

\section{Discussion}

It has been proven by now that reactive oxygen species (ROS) including hydrogen peroxide $\left(\mathrm{H}_{2} \mathrm{O}_{2}\right)$ play an important role in plant-pathogen interaction [17]. ROS can function in the reinforcement of the cell wall by oxidative cross-linking of cell wall components, defense signaling, the hypersensitive response (HR), or be directly toxic to pathogens [18] [19]. Oxalate oxidase and peroxidase are involved in ROS generation in infected plants [20]. Their activation associated with generation of $\mathrm{H}_{2} \mathrm{O}_{2}$ under the influence of salicylic acid and chitooligosaccharides increased wheat's resistance to causative agents of smut and root rot [11]. Fungus pathogens have been shown to increase expression of the genes coding for these enzymes [21]. Thus inoculation of diploid wheat with powdery mildew fungus up-regulated expression of TmPRX1 [4], homologous to peroxidase gene studied by us. Oxalate oxidase also protects plants by degrading oxalates secreted by fungus pathogens and considered as a pathogenecity factor [22]. Thus it is not surprising that in our work the level of expression of OXO gene up-regulated by inoculation was associated with plant resistance to pathogen. The level of PRX gene expression increased sharply in more resistant plants infected with S. nodorum (Omsk 35 and 36) and did not change in less resistant to infection leaves of Bash and Kaz. It is of interest that in some cultivars the level of OXO gene expression up-regulated by inoculation reached its maximum earlier than that of PRX gene. These results suggest greater importance of oxalate oxidase at earlier stages of leaf infection with S. nodorum.

Hydrolytic enzymes (pectinases, proteases etc.) produced by pathogens are important virulence factors [23]. By cleaving components of plant cell walls, these enzymes progressively dissolve the outer barrier of plant cells and enable pathogen to multiply and disseminate within plant tissues. To counteract the activity of fungal hydrolases, many plants express corresponding inhibitors. Interaction of these inhibitors with hydrolases secreted by pathogens limits their destructive potential [24]. Our results showed that inoculation up-regulated expression level of protease inhibitor, while its level in different cultivars correlated to their resistance to infection with wheat leaf blotch pathogen.

Analysis of pectolytic activity and inhibitors of pectinases revealed a more complicated pattern. Inoculation increased pectolytic activity in leaves of cultivars more sensitive to infection and decreased it in more resistant cultivars. The increase in pectinase activity is likely to reflect additional production of the enzymes by fungus pathogen. The decline in pectolytic activity of inoculated leaves of Omskaya 35 and 36 was obviously due to high activity of pectinase inhibitors' characteristic for these cultivars under infection. The level of inhibitors was low in cultivars sensitive to infection with wheat leaf blotch pathogen. 
Thus our results show superiority of cultivars more resistant to infection over the more sensitive ones in terms of level of expression of PRX, OXO and BSI genes, activity of pectinase inhibitors in inoculated plants, and this might have been expected. Nowadays, there is no doubt that generation of ROS, with $\mathrm{H}_{2} \mathrm{O}_{2}$ being among them, is one of the key responses of plant cells to the contact with pathogen resulting in induction of plant defense responses. Thus, in potato tubers of immune cultivar, infection with phytophthora also led to $\mathrm{H}_{2} \mathrm{O}_{2}$ accompanied by hypersensitivity response [25]. In resistant wheat plants infected with the causative agent of brown rust, there was detected intensive generation of ROS in stomata guard cells and leaf mesophyll, where inhibition contributed to the growth and development of pathogen in plant tissues [26]. Oxidases are known to make the greatest contribution to accumulation of $\mathrm{H}_{2} \mathrm{O}_{2}$, oxalate oxidase being the pathogen-inducible protein and the most important component of pro-oxidant plant system [27]. High level of $\mathrm{H}_{2} \mathrm{O}_{2}$ production in infected leaves of cultivar Omsk 35 is likely to be due to enhanced expression of OxO gene. Earlier we revealed activation of oxalate oxidase and increased level of $\mathrm{H}_{2} \mathrm{O}_{2}$ in wheat tissues affected by causative agent of root rods, smut and treatment with inducers of resistance [28]. Moreover, sites of $\mathrm{H}_{2} \mathrm{O}_{2}$ generation are the places of lignin deposition [29]. Anionic peroxidases are known to be implicated in the mechanisms of lignification. It is obvious that increased expression of AP gene enables effective processes of lignin synthesis and contributes to increased resistance of plant tissues to penetration and proliferation of pathogen.

Thus all the mentioned functional characteristics (level of induction of peroxidase and oxalate oxidase genes, protease inhibitor, activity of pectinase under infection) of resistant cultivars surpassed those of susceptible ones indicating the perspective of the use of these traits for selection of resistant plants forms.

\section{Acknowledgements}

This research was financial supported by the Russian Foundation for Basic Research and Russian Education and Science Ministry (state registration No. 01201456414) and Russian Fond of Basic Researchers No. 14-04-97079.

\section{References}

[1] Passardi, F., Penel, C. and Dunand, C. (2004) Performing the Paradoxical: How Plant Peroxidases Modify the Cell Wall. Trends in Plant Science, 9, 365-370.

[2] Almagro, L., Gomez Ros, L.V., Belchi-Navarro, S., Bru, R., RosBarcelo, A. and Pedreno, M.A. (2009) Class III Peroxidases in Plant Defence Reactions. Journal of Experimental Botany, 60, 377-390. http://dx.doi.org/10.1093/jxb/ern277

[3] Berna, A. and Bernier, F. (1999) Regulation by Biotic and Abiotic Stress of a Wheat Germin Gene Encoding Oxalate Oxidase, a $\mathrm{H}_{2} \mathrm{O}_{2}$-Producing Enzyme. Plant Molecular Biology, 39, 539-549. http://dx.doi.org/10.1023/A:1006123432157

[4] Liu, G., Sheng, X., Greenshields, D.L., Ogieglo, A., Kaminskyj, S., Selvaraj, G. and Wei, Y. (2005) Profiling of Wheat class III Peroxidase Genes Derived from Powdery Mildew-Attacked Epidermis Reveals Distinct Sequence-Associated Expression Patterns. Molecular Plant-Microbe Interactions, 18, 730-741. http://dx.doi.org/10.1094/MPMI-18-0730

[5] Minibayeva, F., Kolesnikov, O. and Chasov, A. (2009) Wound-Induced Apoplastic Peroxidase Activities: Their Roles in the Production and Detoxification of Reactive Oxygen Species. Plant, Cell \& Environment, 32, 497-508. http://dx.doi.org/10.1111/j.1365-3040.2009.01944.x

[6] Mika, A., Minibayeva, F., Beckett, R. and Luthje, S. (2004) Possible Functions of Extracellular Peroxidases in StressInduced Generation and Detoxification of Active Oxygen Species. Phytochemistry Reviews, 3, 173-193. http://dx.doi.org/10.1023/B:PHYT.0000047806.21626.49

[7] Davoine, C., Le Deunff, E., Ledger, N., Avice, J.C., Billard, J.P., Dumas, B. and Huault, C. (2001) Specific and Constitutive Expression of Oxalate Oxidase during the Ageing of Leaf Sheaths of Ryegrass Stubble. Plant, Cell \& Environment, 24, 1033-1043. http://dx.doi.org/10.1046/j.1365-3040.2001.00757.x

[8] Gavnholta, B. and Larsenb, K. (2002) Molecular Biology of Plant Laccases in Relation to Lignin Formation. Physiologia Plantarum, 116, 273-280. http://dx.doi.org/10.1034/j.1399-3054.2002.1160301.x

[9] Srinivasan, T., Kumar, K.R.R. and Kirti, P.B. (2009) Constitutive Expression of a Trypsin Protease Inhibitor Confers Multiple Stress Tolerance in Transgenic Tobacco. Plant and Cell Physiology, 50, 541-553. http://dx.doi.org/10.1093/pcp/pcp014

[10] Kudoyarova, G.R., Farkhutdinov, R.G. and Veselov, S.Yu. (1997) Comparison of the Effects of Nitrate and Ammonium Forms of Nitrogen on Auxin Content in Roots and the Growth of Plants under Different Temperature Conditions. 
Plant Growth Regulation, 23, 207-208. http://dx.doi.org/10.1023/A:1005990725068

[11] Burkhanova, G.F., Yarullina, L.G. and Maksimov, I.V. (2007) The Control of Wheat Defense Responses during Infection With Bipolarissorokiniana by Chitooligosaccharides. Russian Journal of Plant Physiology, 54, 104-110. http://dx.doi.org/10.1134/S1021443707010153

[12] Adhikari, T.B., Balaji, B., Breeden, J.D. and Goodwin, S.B. (2007) Resistance of Wheat to Mycosphaerella graminicola Involves Early and Late Peaks of Gene Expression. Physiological and Molecular Plant Pathology, 71, 56-68. http://dx.doi.org/10.1016/j.pmpp.2007.10.004

[13] Shpirnaya, I.A., Umarov, I.A., Shevchenko, N.D. and Ibragimov, R.I. (2009) Evaluation of the Activity of Hydrolases and Their Inhibitors Using Substrates Immobilized on Agarose Gel. Applied Biochemistry and Microbiology, 45, 449453. http://dx.doi.org/10.1134/S0003683809040188

[14] Bindschedler, L.V., Minibaeva, F., Gardner, S.L., Gerrish, C., Davies, D.R. and Bolwell, G.P. (2001) Early Signaling Events in Apoplastic Oxidative Burst in Suspension Cultured French Bean Cells Involve Camp and Ca ${ }^{2+}$. New Phytologist, 151, 185-194. http://dx.doi.org/10.1046/j.1469-8137.2001.00170.X

[15] Efetova, M., Zeier, J., Riederer, M., Lee, C.W., Stingl, N., Mueller, M.J., Hartung, W., Hedrich, R. and Deeken, R. (2007) A Central Role of ABA in Drought Stress Protection of Agrobacterium-Induced Tumors on Arabidopsis. Plant Physiology, 145, 853-862. http://dx.doi.org/10.1104/pp.107.104851

[16] Vierheilig, H., Schweiger, P. and Brundrett, M. (2005) An Overview of Methods for the Detection and Observation of Arbuscular Mycorrhizal Fungi in Roots. Physiologia Plantarum, 125, 393-404.

[17] Lamb, C. and Dixon, R.A. (1997) The Oxidative Burst in Plant Disease Resistance. Annual Review of Plant Physiology and Plant Molecular Biology, 48, 251-275. http://dx.doi.org/10.1146/annurev.arplant.48.1.251

[18] Gohre, V. and Robatzek, S. (2008) Breaking the Barriers: Microbial Effector Molecules Subvert Plant Immunity. Annual Review of Phytopathology, 46, 189-215. http://dx.doi.org/10.1146/annurev.phyto.46.120407.110050

[19] Maksimov, I.V., Valeev, A.S., Cherepanova, E.A. and Yarullina, L.G. (2009) Hydrogen Peroxide Production in Wheat Leaves Infected with the Fungus Septoria nodorum Berk. Strains with Different Virulence. Applied Biochemistry and Microbiology, 45, 433-438. http://dx.doi.org/10.1134/S0003683809040152

[20] Caliskan, M., GeTuret, M. and Cuming, A.C. (2004) Formation of Wheat (Triticum aestivun L.) Embryogenic Callus Involved Peroxide-Generating Germin-Like Oxalate Oxidase. Planta, 2004, 132-140. http://dx.doi.org/10.1007/s00425-003-1199-9

[21] Zhou, F., Zhang, Z., Gregersen, P.L., Mikkelsen, J.D., de Neergaard, E., Collinge, D.B. and Thordal-Christensen, H. (1998) Molecular Characterization of the Oxalate Oxidase Involved in the Response of Barley to the Powdery Mildew Fungus. Plant Physiology, 117, 33-41. http://dx.doi.org/10.1104/pp.117.1.33

[22] Livingstone, D.M., Hampton, J.L., Phipps, P.M. and Grabau, E.A. (2005) Enhancing Resistance to Sclerotinia Minor in Peanut by Expressing a Barley Oxalate Oxidase Gene. Plant Physiology, 137, 1354-1362. http://dx.doi.org/10.1104/pp.104.057232

[23] Murdoch, L., Corbel, J.C., Reis, D., Bertheau, Y. and Vian, B. (1999) Differential Cell Wall Degradation by Erwinia chrysanthemi in Petiole of Saintpauliaionantha. Protoplasma, 210, 54-74. http://dx.doi.org/10.1007/BF01314956

[24] Di Matteo, A., Giovane, A., Raiola, A., Camardella, L., Bonivento, D., De Lorenzo, G., et al. (2005) Structural Basis for the Interaction between Pectin Methylesterase and a Specific Inhibitor Protein. The Plant Cell Online, 17, 849-858. http://dx.doi.org/10.1105/tpc.104.028886

[25] Vasyukova, N.I., Chalenko, G.I., Gerasimova, N.G., Balueva, T.A. and Ozeretskovskaya, O.L. (2008) Activation of Elicitor Defensive Properties by Systemic Signal Molecules during the Interaction between Potato and the Late Blight Agent. Applied Biochemistry and Microbiology, 44, 236-240. http://dx.doi.org/10.1134/S0003683808020154

[26] Plotnikova, L.Y. (2009) Participation of Reactive Oxygen Species in Protection Wheat Lines with Genes Stability of Species Agropyron Brown Rust. Russian Journal of Plant Physiology, 56, 200-209. http://dx.doi.org/10.1134/S102144370902006X

[27] Mur, L.A.J., Kenton, P., Atzorn, R., Miersch, O. and Wasternack, C. (2006) The Outcomes of Concentration-Specific Interactions between Salicylate and Jasmonate Signaling Include Synergy, Antagonism, and Oxidative Stress Leading to Cell Death. Plant Physiology, 140, 249-262. http://dx.doi.org/10.1104/pp.105.072348

[28] Troshina, N.B., Maksimov, I.V., Yarullina, L.G., Surina, O.B. and Cherepanova, E.A. (2004) Effect of Salicylic Acid to Generate Hydrogen Peroxide in the Wheat Calli Cells Infected by Smutpathogen. Tsitologiia, 46, 1001-1005.

[29] Boudet, A.M. (2000) Lignins and Lignification: Selected Issues. Plant Physiology and Biochemistry, 38, 81-96. http://dx.doi.org/10.1016/S0981-9428(00)00166-2 
Scientific Research Publishing (SCIRP) is one of the largest Open Access journal publishers. It is currently publishing more than 200 open access, online, peer-reviewed journals covering a wide range of academic disciplines. SCIRP serves the worldwide academic communities and contributes to the progress and application of science with its publication.

Other selected journals from SCIRP are listed as below. Submit your manuscript to us via either submit@scirp.org or Online Submission Portal.
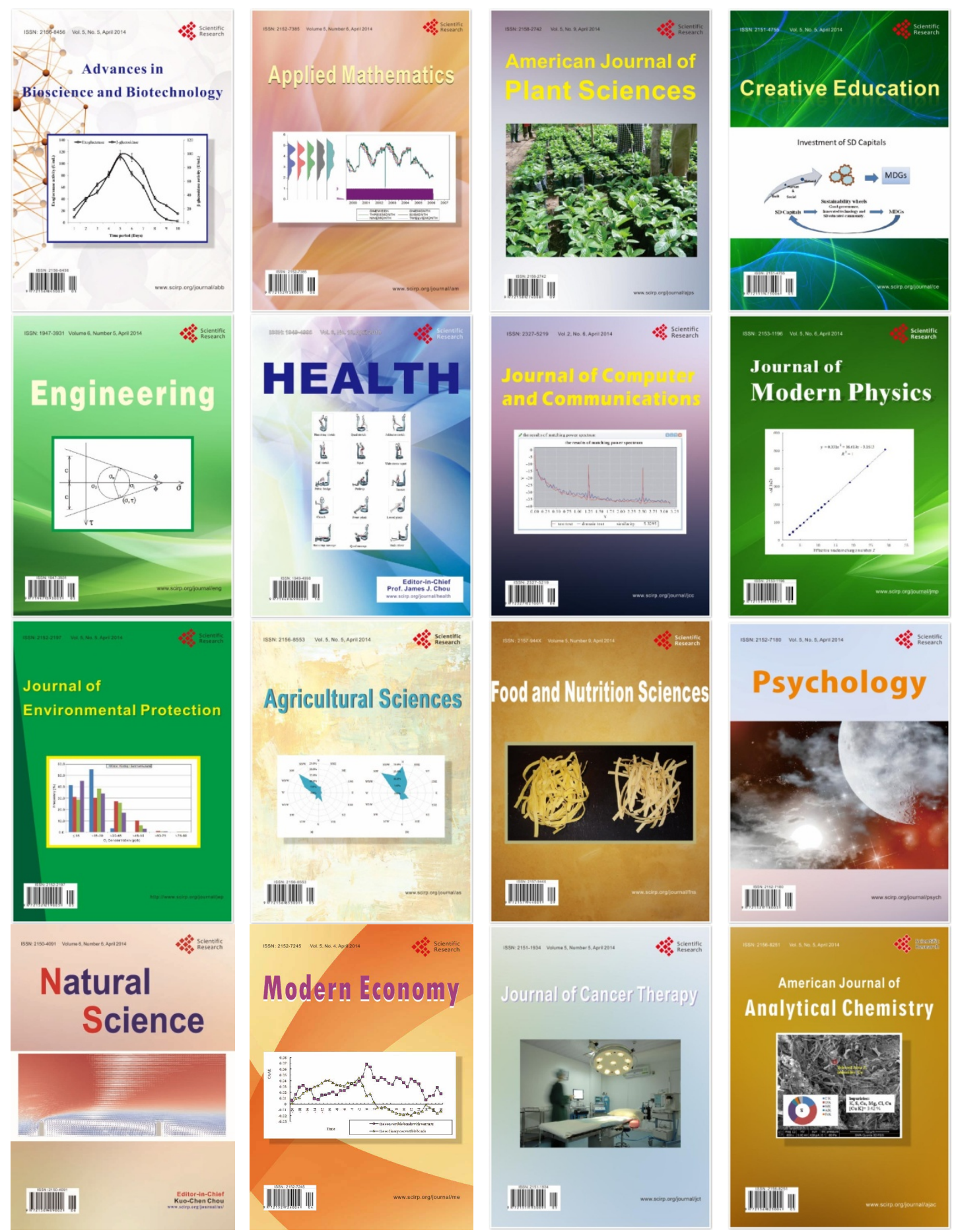